\title{
Politics and Politicians in Soviet Belarus: The Case of Kiryla Mazurau
}

\author{
BY \\ ANGELIKA POBEDONOSTSEVA KAYA
}

\author{
Natallia Golubeva \\ Kiryla Mazuraŭ. O chem molchalo vremia. \\ Minsk: Bielaruskaja encyklapedyja imia Piatrusia Broŭki, 2018. 416 s.
}

The book by Natalia Golubeva on Kiryla Mazuraŭ presents an attempt to produce a biography of a leader of Soviet Belarus which includes some criticism of the Soviet past without a fundamental deviation from the conceptual and methodological approaches of late Soviet times. As a result, it makes this book sound as if it is a voice from the 1980s on some pages.

In general, the publication almost completely avoids discussing the contradictions inherent in the professional, political and private life of one of the leaders of Soviet Belarus. It draws a picture of the consistent rise of a Belarusian peasant to the top of the Soviet state and party system and his subsequent abrupt fall. In parallel, the private and family life of the person in focus seems to develop in a similarly upward manner until he dies. The exemplary life of an exemplary Soviet statesman?

Yet even some facts and quotations provided in the book undermine this idyll. So, Mazuraŭ is portrayed as desperate with regards to his own professional prospects in the 1930s and disappointed about what he had to do to implement Soviet policies. In his personal life, he is described as having married relatively later than was generally expected for that epoch, at the age of 31 , which raises questions about possible omissions in describing his personal life.

Despite this approach which sometimes borders on hagiography, the author cautiously uncovers some facts which were suppressed in Soviet times, and, by rather detailed discussion of the subject matter, encourages the reader to reinterpret them. This begins with describing the social background of Mazuraŭ as coming from a rich peasant family (pp. 15 and 18). His father, however, had anticipated the new trends of the political situation at the time and and timely got rid of their 
property to avoid persecution. At the same time, he sent his son, Kiryla, to a school and, later, the Road Construction College in the nearby city of Homiel.

After graduation, Kiryla Mazuraŭ was ordered to go find a job in the Paryčy District of Palesse Province which, however, had no work for him as a road construction technician. Although the country had just recently made most of its citizens literate, and, certainly, lacked the qualified cadres, Mazuraŭ was appointed as the mere Chairman of a Communist Youth Union (Komsomol) cell in a faraway village and even worked there tilling soil. He had to be responsible for about 14 Komsomol members and observed the disastrous situation in the village brought about by recent collectivisation.

Later on, he complained that there he "used to waste his energy by beating out the remnants of independence and diligence from yesterday's peasants, as well as the fruits of their labour" (p. 30). Description of the socioeconomic catastrophe of that time, and Mazuraŭ's perception of political repressions, therefore composes a large part of the book.

He was able to flee that predicament only by getting a job helping with the construction of the Moscow metro, but his work there lasted only a few months and soon he had to return to Belarus. Golubeva provides no clear picture of this Moscow episode and why it ended in failure. It seems, however, that Mazuraŭ became so disappointed with his own situation after that mysterious episode that he even decided to urgently sign up for military service in 1936. After a two yearstint in the Red Army, Mazuraŭ's career prospects seemed to improve yet the offered in this publication remain controversial and opaque. On one page Golubeva says he worked in the Homiel Province Committee of the Komsomol (p. 36), on another she states that he was instead appointed to the Political Department of the Belarusian Railway in Homieĺ (p. 33).

His time, finally, came in 1940 as he was appointed First Secretary of the Brest Province Committee of the Komsomol. This boost to his career became possible because of the recent territorial expansion of Soviet Belarus, implies Golubeva. She quotes notes which reveal how surprised Mazuraŭ was by the low educational level of the population in the new provinces united with Soviet Belarus (p. 38) which, of course, created new opportunities for the rapid professional rise of the cadres from Eastern Belarus.

A revealing part of the book constitutes the description of the subsequent wartime experience. Sent to organise resistance movements in the occupied territories, he left notes which demonstrate the numerous contradictions of the struggle there. His official functions and undoubted commitment to the Communist party make these observations especially valueable. 
Thus, he describes an extremely bad situation which affected the availability of numerous supplies (he had even ask Moscow for some clothing, footwear and a cap for himself and his close collaborators (p. 51)), which somehow improved later but still continued to cause difficulties until the end of Mazuraŭ's mission. Arms and munitions supplies were also affected. In addition, Mazuraŭ points out that some partisan units not only behaved badly towards the local population, but committed crimes as well. In addition, there were conflicts between local guerrilla units and partisans' detachments sent from Moscow.

Against this backdrop, the content of Mazuraŭ's interview with the former leader of the Soviet Belarus Panceliajmon Panamarenka (pp. 49-50) is given a new meaning, although it might be the case that the author of the book did not intend it to be so. Panamarenka told Mazuraŭ of a fierce debate which had occurred at the start of the mobilisation of guerrilla activities in occupied regions at the very top of the Soviet leadership. At that time Panamarenka, inter alia, had to argue against People's Commissar for Internal Affairs, Lavrentii Beria's, opinion that only specially trained military units should be sent behind to the front to carry out subversive operations, and that the partisan units formed by ordinary citizens in occupied regions were militarily useless, and, hence, should not be allocated much support.

After the war, since 1948, the rapid rise of Mazuraŭ almost to the top of the Soviet party and state hierarchies reached a new level. First, he became Secretary of Minsk City and then the Minsk Party Committee. The author succeeds in drawing a remarkable and contradictory picture of the time. On the one hand, the reconstruction of the ruined economy, on the other, repressions on political and social grounds. In addition, she relates some remarkable facts which undermine cliches about the successes of the system of complete control in place in the BSSR at the time. For instance, she quotes official reports on the lack of interest in Stalin's works felt by the Komsomol youth. Or to give another example, according to Mazuraŭ - Beria was not perceived by Stalin as a powerful figure, unlike Beria's man in Minsk, Lavrenti Tsanava. The latter, insists Mazuraŭ, had ruthlessly terrorised Soviet Belarus, and he then illustrates his point further with a story about Tsanava's embarrassment caused by Mazuraŭ's later action. This did not bring about, however, any negative consequences for Mazuraŭ (p. 124-126).

In 1953-1956, as Prime Minister of the BSSR, Mazuraŭ is described as having supported the rising Khrushchev's faction aiming for Soviet leadership. He was among those who, in June 1953, resisted Beria's attempts to bring more representatives of the so-called titular nationalities into the leadership of national republics. For Belarus, this meant dismissal of the current leader of the Republic, Mikalai Patoličaŭ, who was ethnically Russian. Yet such a move was defeated by the Central Committee of the Communist Party of Belarus. To interpret this as a 
lack of national self-consciousness would be too easy a conclusion to come to: it is probable that many officials in Minsk perceived Beria's move as merely a trick in the struggle for power in the Kremlin. Unfortunately, no analysis of this extremely interesting clash of views can be found in the book.

The parts of the book which deal with Mazuraŭ's work in Minsk as the BSSR Prime Minister and the CPB First Secretary contain a description of different political moves, situations as well as recollections reporting the political atmosphere at the time. The author, however, avoids raising any conceptual questions, although several fundamental issues could have been discussed at this point. Among them, the question of how much decision-making the leaders of the BSSR were responsible for removing; to what extent the interests of the BSSR per se vs. the interests of the entire Union were considered in such decision-making; how Mazuraŭ's performance in the top offices of the BSSR differs in comparison to the performance of others who held those positions. Golubeva makes certain claims with regard to these seminal issues and does provide some evidence scattered throughout the entire text. What is lacking is a coherent argument based on coherently presented evidence.

In 1956-1965, as First Secretary of the Communist Party of Belarus, Mazuraŭ had the most opportunities to shape the Republic. Golubeva cites some interesting cases which imply that there was, perhaps quite often, severely restricted yet real politics at the heart of developing, taking and implementing decisions important in the BSSR at the time as a result of the conflict of opinions held by indivduals within society. In other words, many major decisions influencing the development of the Republic were made in Belarus itself, or at least the government of the BSSR made a considerable contribution to the making of the decisions in question.

So, she insists that it was Mazuraŭ's efforts which resulted in the building of a major oil refinery in Belarusian Navapolack in the mid-1950s, the transfer of more powers related to urban development away from the Ministries to the Minsk City Council and the intensive development of energy generation facilities focused on mineral extraction and other similar industrialisation moves (pp. 152-153; 156-158). She quotes the KGB General Eduard Nordman as saying, "despite the availability of scientific and technical cadres, it was necessary to break the inertia of the central planning bodies and Ministries, which, at first, were also cautious about the establishment of factories manufacturing sophisticated products in Belarus. It was necessary to argue and convince... And that was done. Mazuraŭ was well known [for that], not only in the CC of the CPSU, but also in the Government of the USSR, in Gosplan, Ministries...” (p. 161).

While discussing this period, sometimes, the book also presents interesting evidence regarding the fundamental political issues of the time without making 
any additional points. For instance, how the citizens were able to influence the decisions taken by the BSSR government and CPB Party bodies via direct contact with top officials. The book only cites the example of the unemployed citizens putting pressure on officials to provide them with jobs in the 1950s (p. 153), and then drops the issue.

During the years 1965-1978, when Mazuraŭ served as Deputy Prime Minister of the USSR, the Soviet Union reached the height of its power and prosperity. Moreover, that was a time when ethnic Belarusians were widely represented in the Soviet Union's leadership. Indeed, the CIA's Soviet analysts even spoke later of a "Belarusian faction" in Soviet leadership (p. 339). They specifically focused on Mazuraŭ and Mašeraŭ. Indeed, active at the very top of the Soviet Union political elite alongside Mazuraŭ during this time period were such figures as Foreign Minister Andrei Gromyko, Main Intelligence Directorate (GRU) Head Piotr Ivashutin, Soviet elite paratroopers' forces Commander Vasili Margelov and Deputy Head of International Department of the Central Committee of the CPSU Rostislav Ulyanovski, all of them responsible for major political and military decision-making.

Unfortunately, the chapters of the book dedicated to Mazuraŭ's time as Deputy Prime Minister of the USSR are its weakest part. This is especially applicable to Golubeva's presentation of Mazuraŭ's diplomatic activities (pp. 288-336).

That is remarkable because the role of Kiryla Mazuraŭ in the government of the Soviet Union is evident. During his time in office, he was responsible for the performance of 29 Union-level Ministries, a series of economic reforms and experients as well as huge projects within the USSR, like the Baikal-Amur Mainline (BAM), and abroad, like the Aswan Dam in Egypt. Golubeva calls this "a tandem Kosygin-Mazuraŭ" and Mazuraŭ himself proudly announced that the "time of the eighth five-year plan [1966 - 1970, as he managed Soviet economy alongside Soviet Prime Minister Kosygin] has been the most productive in the entire history" of the USSR (pp. 238-241).

The author reconstructs the atmosphere of this time and how the former Belarusian leader managed to deal with the governance of a much large country. This was apparently not easy as the cited contradictions illustrate. Thus, Mazuraŭ as a top Soviet official, not only stood out for his more open approach which involved broader consultations, but he also invested a lot of time in visiting various locations of the USSR to personally see the situation for himself. A conflict with Brezhnev even ensued from this and the latter then initiated a decision which restricted the travel of the members of the Political Bureau of the CPSU CC (pp. 266-267).

The undoubtedly important role of Mazuraŭ in the BAM construction is considered in a separate chapter (pp. 262-267), but the only cited specific evidence 
on it is limited to a cable inviting him to attend the inauguration ceremony of a segment of the BAM and his standard response to it. The rest of the chapter either does not relate to Mazuraŭ at all, or relates to Mazuraŭ, but not to the BAM, or repeats well-known facts linked with his involvement in this project.

The Diplomatic activities of Mazuraŭ included many significant contacts and events of global scale. As early as 1955, he participated in the establishment of the Warsaw Pact as a member of the Soviet delegation. According to his own claims, it was he and some other top officials of the Soviet government and Party, rather than Khrushchev, who were involved in the everyday management of the 1962 Cuban Missile Crisis (pp. 291-292). But, of course, the most wellknown diplomatic mission Mazuraŭ undertook was during the 1968 crisis over Czechoslovakia, when he, as a member of the CPSU Political Bureau, was sent to oversee the military operation there. The book only repeats well-known facts on the Czechoslovak mission, whilst embellishing them with a few personal remarks from Mazuraŭ himself. Even worse, the author uncritically quotes some chauvinist claims and observations, above all, by Soviet military officers, with regard to the Czechs. Actually, the uncritical handling of chauvinistic and biased claims in quoted recollections is glaringly evident in several parts of the book.

The superficial attention given to Mazuraŭ's diplomatic missions is a pity because the archives he left behind contain a lot of valuable primary sources not yet used by Cold War scholars. The value of the materials can be seen from his notebook observations on relations with various European and Asian countries which are arbitrarily quoted by Golubeva without serious analysis or comments (pp. 322-326). Even at first glance, there one can see the interesting details of how this Soviet top-level official viewed the prospects of the Vietnam War, the situation in Indonesia before the coup d'état, the bloody massacre of Communists there or the Japanese threat. It would be logical to analyse these notebooks to identify where inside the Kremlin's leadership Mazuraŭ stood on issues affecting international politics or draw some conclusions on Mazuraŭ as a diplomat. The book's author limited herself to only publishing fragments of the notebooks for the first time.

The second part of Mazuraŭ's previously unpublished observations from the notebook also contains really important and previously unpublished information on his conversations with Egyptian leader Gamal Abdel Nasser, Syrian leader Hafez Assad and one of the leaders of Yugoslavia Edvard Kardelj. It concerns, for instance, Egypt's break from the Soviet Union but the author, unfortunately, not only makes no effort to analyse these notebooks but even has problems with transcribing the handwritten notes and confuses Iran and Iraq repeatedly (pp. 332-335).

Golubeva insists that the decline and fall of Mazuraŭ has much more to do with the rising influence of Yuri Andropov than with any conflicts of the Belarusian 
Soviet politician with Brezhnev. According to her, this might be rooted in some previous conflicts in which Mazuraŭ took actions against Andropov's son and comrades (pp. 347-349). But next she speculates that it might be the case that Andropov was merely demonstrating how important and promising the foreign media considered Mazuraŭ to be to Brezhnev, and so was essentially forcing him to dismiss the former Belarusian leader out of jealousy. But the only evidence used in this chapter includes fairly standard quotes from Western media. Anyway, health conditions were quoted as the official reason for the dismissal but Golubeva does not take this explanation seriously. Therefore, the dismissal of Mazuraŭ in November 1978 from the Soviet government and Party top bodies remains without an explanation supported by sufficient evidence. To find one is probably possible today, however: Mazuraŭ lived untill 1989 and left behind the unpublished memoirs and archive used in writing the book reviewed here.

After reading the monograph, Kiryla Mazuraŭ gives the impression of what the Belarusian political lexicon of recent decades calls a "clever manager" [krepki khozyaistvennik]. His commitment to the Soviet state and party system is more a commitment to a statist worldview rather than a deep belief in MarxistLeninist ideology. The book contains many quotes which illustrate his attitude to Communism as a sort of political liturgy when he cites Communist dogmas as a kind of lip service. He admits to having doubts about Soviet government policies and figures as early as 1935 when he was sent for a while to work on the Moscow metro construction project (pp. 30-31).

Among the achievements of the book is the author's convincing case for the strength of Mazuraŭ's Belarusian identity. He himself refers to Belarusian literature and his encounter with a famous poet of the 1920s, Mihas Čarot, in scarce yet sufficient details to prove his knowledge of it (p. 22). Immediately after the war, in his spare time, Mazuraŭ started translating the entire collection of Lenin's works into Belarusian and completed as many as three volumes. Until the end of his life he was friends with another poet, Piatruś Broŭka, and there is evidence of there being at least one, however amateur, piece of poetry of his written when he was already the BSSR leader in Belarusian. Golubeva also mentions other support provided to Belarusian artists and literators, as well as Belarusian educational institutions, during the time when Mazurau led the BSSR yet avoids any specifics.

However, she does remind the reader that, in the most spectacular way, Mazuraŭ's commitment to Belarusian culture expressed itself in his clash with Khrushchev. At the ceremony held to celebrate the 40th anniversary of the BSSR in 1959, Mazuraŭ chose to speak in Belarusian, inciting the ire of Khrushchev and allegedly making him say that the sooner one starts speaking Russian, the further one will go along the path to Communism (pp. 395-397). Sure, Mazuraŭ's 
support for the Belarusian language and education in this language at the end of his life, in April 1988, was rather cautious, but he did express it publicly, nonetheless. Moreover, he did it in Belarusian (pp. 410-411).

Despite this uneven quality of factual analysis, the book has a nice structure with rather short subsections with clear headings. To provide a contextual background, some quotes are highlighted. However, the sources of the quotes and cited facts are not named in many cases. The quotations frequently lack references, although the reader can guess where the quote is taken from. On the one hand, the Golubeva did a praiseworthy job in even using some video materials, but on the other, some sources are simply dubious, as, for instance, when she cites an older Duke University study by referring to an article on a popular Ukrainian website (p. 247).

While the author extensively worked with primary sources and unpublished materials, and consulted many contemporary publications and some studies in Russian and Belarusian, too much emphasis was put on the archive of Mazuraŭ himself. No attempt was made to cross-examine the information from his collection with other documents, and even very obvious and easily-accessible sources which have direct relevance for such a study on Mazuraŭ's life, are glaringly absent. For instance, that is the case with the part of the book which describes the times Mikalai Patoličaŭ was leader of Belarus: the author did not use his memoirs in her book at all. ${ }^{1}$

The book would benefit a lot from being linked to existing global scholarship on Soviet history as far as methodology and concepts are concerned. The fact that this was not done is especially remarkable because the author actually made some, although very limited attempts, at using foreign sources directly (p. 339).

In many cases, only one side of the story is presented without the slightest reference to alternative views (that is so every time the book deals with antiSoviet organisations). The author avoids taking a critical approach to analysing the sources, choosing to merely cite them without the slightest questions raised about the motives and veracity of a particular document.

Among the positive aspects of the book is the presentation of several dozen unique photos, both of the historical individuals involved and some valueable documents. Among the latter are a KGB pencil-written report on political repressions (p. 87) and a unique map of partisan and underground networks as of September 1941 (remarkably, in Belarusian, pp. 374-375).

The inclusion of ordinary moral sermons and the use of the emotionally-charged style (e.g. on sending peasant families into exile on p. 124) undermine the scholarly

\footnotetext{
1 Патоличев Н. С. Испытание на зрелость. - М.: Политиздат, 1977; and Патоличев Н. С. Совестью своей не поступись. - М.: Сампо, 1995. Patolichev, N., 1977. Ispytanije na zrelost', Moskva: Politizdat; and Patolichev, N., 1995. Soviest'ju svojei ne postupis, Moskva: Sampo.
} 
character of the book, though they may be morally sound. Some sections have no relation to the subject matter altogether, and their presence can be explained only by the author's efforts to cater to current political developments. A case in point is a section on a territorial dispute between Belarus and Ukraine immediately after their unification with their western provinces. It is artificially linked to Khrushchev's decision to transfer the Crimea to Soviet Ukraine in 1954 and, without any evidence cited, Golubeva claims that Khrushchev also wanted to transfer some regions of the BSSR to Ukraine in the 1950s as well but did not dare because of the allegedly resolute opposition of the Belarusian leadership (pp. 232-233).

To summarise, though Golubeva's book is not the first publication on Kiryla Mazuraŭ it is the first attempt at writing a biography of this Belarusian politician. The book has the potential to make a contribution to such a biography as it presents in many regards a valuable description of Mazuraŭ's life as well as some materials from his archival collections. But the book itself is rather a popular publication: it lacks too many things to be deemed a proper scholarly biography. 